\title{
Livestock redistribute runoff and sediments in semi-arid rangeland areas
}

\author{
P. Sarah and M. Zonana \\ Laboratory of Geomorphology and Soil, Department of Geography and Environment, \\ Bar Ilan University, Israel \\ Correspondence to: P. Sarah (sarah.pariente@biu.ac.il)
}

Received: 13 October 2014 - Published in Solid Earth Discuss.: 5 December 2014

Revised: 23 February 2015 - Accepted: 18 March 2015 - Published: 29 April 2015

\begin{abstract}
Semi-arid areas where grazing is the main land use exhibit a "three-phase-mosaic" pattern of dominant surface patches: shrubs, trampling routes, and intershrub areas. This pattern differs from the "two-phase mosaic" seen in grazing-free semi-arid areas. The patches might create a positive feedback process in which enhanced infiltration beneath shrubs minimizes overland flow from under their canopies, thereby strengthening the sink-source mechanism by which overland flow generated between shrubs rapidly infiltrates into the soil beneath them, where it deposits soil particles, litter, nutrients and organic matter, thereby enhancing infiltration by changing the local microtopography, and improving soil properties. To analyze sink-source relationships among the patches in grazed areas in rangelands of the semi-arid northern Negev region of Israel, we constructed small runoff plots, $0.25-1.0 \mathrm{~m}^{2}$ in area, of five types: shrub (Sarcopoterium spinosum), intershrub, route, route-shrub combination, and intershrub-shrub combination. The shrubs always occupied the downslope part of the plot. Overland flow and sediment deposits were measured in all plots during 2007/8 and 2008/9. The combined plots yielded much less overland flow and sediments than intershrub, routes and shrub ones, indicating that the shrubs absorbed almost all the yields of the upper part of their plots. The shrubs generated less runoff and sediments than routes and intershrubs; runoff flows from the routes and intershrubs were similar; sediment yield was highest in the intershrubs. Thus, runoff yield exhibited a twophase mosaic pattern, and sediment yield, i.e., soil erosion, a three-phase mosaic pattern.
\end{abstract}

\section{Introduction}

Grazing has been seen as one of the key causative factors of desertification in semi-arid ecosystems (Cerdà et al., 2010), because of the increases in soil erosion and runoff discharge, caused, in turn, by exhaustion of the vegetation and the encroachment of bushy plants (Angassa, 2012). This has led to use of enclosure to control grazing intensity (Mekuria and Aynekulu, 2013), and to control of stocking rates (Vetter and Bond, 2012). However, land management is now being seen as the main cause of land degradation and desertification (Bennet et al., 2012), and grazing more as a solution than a problem, if the management is appropriate (ÁlvarezMartínez et al., 2013). Some authors found that grazing is a sustainable and necessary land use (Shang et al., 2014) to maintain a healthy environment (Jones et al., 2014; Mulale et al., 2014; Carreiras et al., 2014). Grazing can involve positive impacts on ecosystems such as increasing the total bud bank density and stimulating plant growth (Qian et al., 2014), managing the biomass, restoring pastures invaded by shrubs (Álvarez-Martínez et al., 2013), to avoid wildfires, which are the cause of intense soil erosion (Lasanta and Cerdà, 2005). Arid and semi-arid environments are characterized by a non-uniform ground surface cover, comprising various components such as vegetation, bare soil, exposed bedrock, rock fragments, and crusts (Cerdà, 1997; Lavee et al., 1998; Calvo-Cases et al., 2003; Arnau-Rosalén et al., 2008; Dickie and Parsons, 2012; Kakemboey al., 2012; Kröpfl et al., 2013). Each component constitutes a separate microenvironment, with its own pedological, hydrological, ecological and geomorphological behavior (Yair and Lavee, 1985; Li and Sarah, 2003), driven by complex interactions and feedbacks (Sarah, 2003). The spatial distribution 
of the microenvironments is a main key, on the one hand, to understanding the various ecogeomorphic processes that shape the landscape, on the other hand, and to explaining the complex hydrology of semi-arid environments. The effect of the patchy distribution of vegetation on hillslope hydrology and soil erosion found to be more pronounced than that of the hillslope position (Cerdà, 1998a). The strongly coupled ecological-hydrological system of vegetation and open areas is of great importance in analyzing these processes, because of the patchy distribution within the landscape of essential resources such as water, soil particles, organic matter, and nutrients (Bergkamp, 1998). This patchiness creates a complex matrix of source-sink microenvironments (Bergkamp, 1998; Puigdefabregas et al., 1999), in which the shrub patches act as sinks for water and water-borne resources, and patches of bare soil act as sources (Yair and Lavee, 1985; Cerdà, 1998a; Lavee et al., 1998; Li and Sarah, 2003; Calvo-Cases et al., 2003). This matrix supports the following positivefeedback process. The enhanced infiltration beneath shrub patches minimizes overland flow under their canopies and thereby strengthens the sink-source mechanism by which overland flow generated in the bare-soil patches rapidly infiltrates into the soil beneath the shrubs (Bergkamp, 1998; Lavee et al., 1998; Sarah, 2002; Calvo-Cases et al., 2003; Ben-Shmuel, 2005). At this point, it deposits soil particles, litter, nutrients and organic matter, which, in turn, enhance the infiltration rate in the shrub patches by changing their micro-topography (Stavi et al., 2008a) and improving the texture, structure and aggregate stability, porosity, fertility and chemical composition of their soil (Puigdefabregas and Sanchez, 1996; Cerdà, 1998d; Rietkerk et al., 2002; CalvoCases et al., 2003). Patchiness of plants, which affects the soil aggregate stability, found to be one of the key factors of reinforcement of the ecogeomorphic system (Cerdà, 1998d). Thus, patchiness represents a self-organized hillslope system, which maximizes harvesting of runoff, minimizes losses of sediment and nutrients, and thereby retains water and soil resources within the system (Shachak et al., 1998; Tongway and Ludwig, 2003). The spatial distribution of these two patch types was designated as a two-phase mosaic by many authors (e.g., Bergkamp, 1998; Eddy et al., 1999; Galle et al., 1999; Ludwig et al., 1999). This pattern has been shown to have significant consequences for the water-infiltration characteristics of semi-arid hillslopes (Abrahams and Parsons, 1991) because the vegetation in these environments is sustained by overland flow from bare soil in the open spaces between shrubs (Puigdefabregas and Sanchez, 1996). On hillslopes subject to grazing, as in the northern Negev region of Israel, the mosaic pattern is more complicated; the open spaces between shrubs comprise two components, i.e., areas with herbaceous vegetation, separated by trampling routes that support no vegetation. Therefore, the clearly visible routes were considered to differ from the remainder of the intershrub area with regard to pedohydrological characteristics, and were designated as a third type of surface cover, in addition to the shrubs and herbaceous areas; grazing induces a modification of semi-arid rangelands from two-phase to three-phase mosaic geoecosystems (Sarah, 2009; Stavi et al., 2012).

Conclusions regarding the redistribution of runoff and sediments in rangelands were based on theoretical deductions derived from pedohydrological properties such as hydraulic conductivity (Bromley et al., 1997), infiltration capacity (Eldridge et al., 2000), soil moisture (Sarah, 2002; Katra et al., 2007) and organic matter contents (Sarah, 2006), penetration resistance (Manzano and Navar, 2000; Stavi et al., 2008b), vegetation properties (Puigdefabregas et al., 1998; Shachak et al., 1998; Golodets and Boeken, 2006), or simulation models (Ludwig et al., 1999; Puigdefabregas et al., 1999).

Many studies have dealt with the causes and processes of runoff generation and sediment movement in semi-arid environments (e.g., Yair and Lavee, 1981, 1985; Cerda, 1998a, b, c; Lavee et al., 1998; Calvo-Cases et al., 2003; ArnauRosalén et al., 2008). These processes include leakage of water and resources from the ecosystem (Shachak et al., 1998), and preservation of water and resources by retention in shrub or vegetation patches on hillslopes (Bromley et al., 1997; Bergkamp, 1998; Puigdefabregas et al., 1998, 1999; Ludwig et al., 1999). Most of these studies were based on rainfall simulation experiments in the field (Yair and Lavee, 1981, 1985; Lavee et al., 1991; Parsons et al., 1992; Bergkamp, 1998; Cerda, 1998c; Calvo-Cases et al., 2003; Arnau-Rosalén et al., 2008) or in the laboratory (Bryan, 2000); others were based on visual estimations (Bromley et al., 1997; Bergkamp, 1998). Furthermore, studies on runoff and sedimentation processes under natural rainfall conditions were conducted on medium and relatively large scales, i.e., part or all of the hillslope or catchment (e.g., Puigdefabregas et al., 1998, 1999; Bergkamp, 1998; Parsons et al., 1992); virtually all the studies based on small-scale runoff plots in the field used simulated rainfall and resembled one another in the means of application: they involved rainfall intensity of 50$55 \mathrm{~mm} \mathrm{~h}^{-1}$ during 45-60 min (Imeson et al., 1996; Cerdà, 1998b; Calvo-Cases et al., 2003; Arnau-Rosalén et al., 2008).

In spite of the numerous studies cited above, in a survey of hydrological and erosion data obtained under natural or simulated rainfall on limestone landscapes in various Mediterranean environments in the last 15 years, Calvo-Cases et al. (2003) found that, although several different environmental factors- climate, topography, lithology, soil surface cover, land use- were addressed, only a few studies took grazing into account.

The objectives of the present paper were as follows: to confirm the role of shrub (Sarcopoterium spinosum) patches as sinks for water (rainfall and overland flows) and sediments; to confirm the role of the open areas between shrubs (routes and the remaining intershrub patches) as sources under natural rainfall, in rangelands of the northern Negev in Israel; and to determine to what extent the patches differ in their overland flow generation and sediment production in 


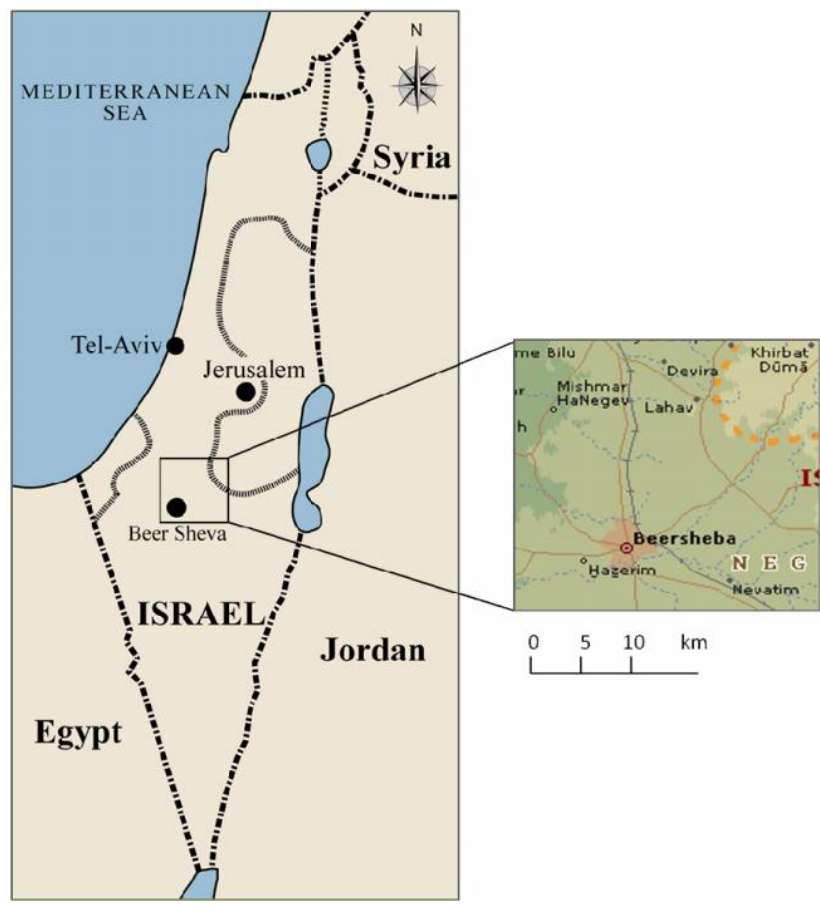

Figure 1. Map of Israel, showing the study region.

this area. It was hypothesized that the three types of surface cover/patches would differ in their responses to rainfall, and that the routes and the shrubs, respectively, would yield the highest and lowest outputs of overland flow and sediments, with those from the intershrubs falling between them.

\section{Materials and methods}

\subsection{Study area}

The research was conducted in the Goral Hills in the northern Negev region of Israel $\left(31^{\circ} 20^{\prime} \mathrm{N}, 34^{\circ} 46^{\prime} \mathrm{E}\right.$; Fig. 1). This is a hilly, semi-arid area, lying $350-500 \mathrm{~m}$, with mean annual precipitation of $300 \mathrm{~mm}$, most of which falls during the cold season - October-May (Perevolotsky and Landau, 1988; Osem et al., 2002). The winter is cold and rainy, with average daily temperature in January, the coldest month, of $10^{\circ} \mathrm{C}$; the summer is hot and dry, with average daily temperature in August, the hottest month, of $25^{\circ} \mathrm{C}$. Relative humidity ranges between $51 \%$ in May and $68 \%$ in January (Bitan and Rubin, 1991; Bar'am, 1996). The lithology is chalk and limestone of the Eocene (Ravikovich, 1981, cited in Osem et al., 2002). The soil, Leptosols, is shallow, generally not deeper than 20 and $40 \mathrm{~cm}$ in open spaces between shrubs and under shrubs, respectively, except in rock fissures. The color of dry soil is pale brown (7.5 YR 6/3) and that of wet soil is brown (7.5 YR 4/3); the texture, on average, is clay loamy in which the primary particle-size distribution is $20-30 \%$ clay, $40-50 \%$ silt and $30 \%$ sand (Zwikel et

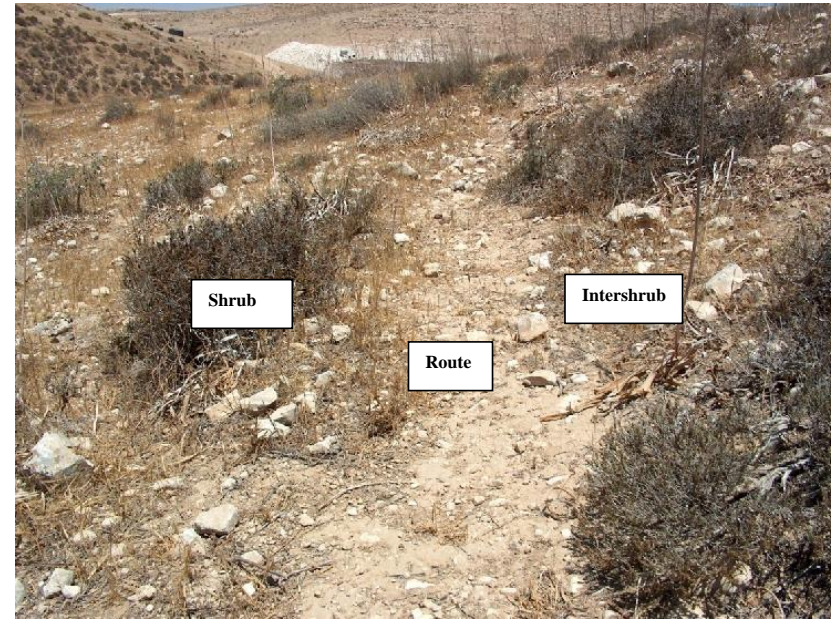

Figure 2. Three main types of surface cover in the research site.

al., 2007). The cation-exchange capacity (CEC) is $16 \mathrm{meq}$ per $100 \mathrm{~g}$ in the uppermost $(0-5 \mathrm{~cm})$ layer, and the cation distribution in this layer (in meq per $100 \mathrm{~g}$ ) is $\mathrm{Ca}^{2+}, 12.9$; $\mathrm{Mg}^{2+}, 0.5 ; \mathrm{K}^{+}, 1.3$; and $\mathrm{Na}^{+}, 0.7$. The dominant clay type is smectite, and the stone content is about 15-30\% (Dan and Koyumdjisky, 1979; Zwikel et al., 2007). The mean gradient of the hillslopes is $15^{\circ}$. The study area, like many other semiarid areas of the Old World, has been grazed by flocks of sheep and goats since prehistoric times, i.e., for 5000-8000 years; therefore, the vegetation mainly comprises grazingtolerant species (Noy-Meir and Seligman, 1987). The vegetation physiognomy comprises sparse shrubland containing a patchy distribution of vegetation, biological crusts, exposed bedrock, and bare soil. The vegetation includes: (a) dwarf shrubs, mainly Sarcopoterium spinosum, Coridothymus capitatus, andThymelaea hirsute; (b) perennial grasses and forbs, mainly Asphodelus ramosus and Poa bulbosa; and (c) annual herbaceous vegetation (Osem et al., 2002). The research area is occupied by flock trampling routes, shrubs, and intershrub spaces, which cover 22,17 , and $61 \%$, respectively, of the landscape (Stavi et al., 2008b).

\subsection{Field work}

Observations in the research area have revealed three main types of surface cover: shrubs, flock trampling routes, and intershrub areas (Fig. 2).

In order to confirm the sink-source relations among the dominant types of surface cover, several different small runoff plots, of area ranging from 0.25 to $1.0 \mathrm{~m}^{2}$, were constructed on the central parts (back slopes) of south-facing hillslopes: three of them contained shrub, Sarcopoterium spinosum (SH), intershrub (IS), and route (RU), respectively; two contained combinations of route and shrub (SR), and of intershrub patches and shrubs (SI), with the shrub(s) always 


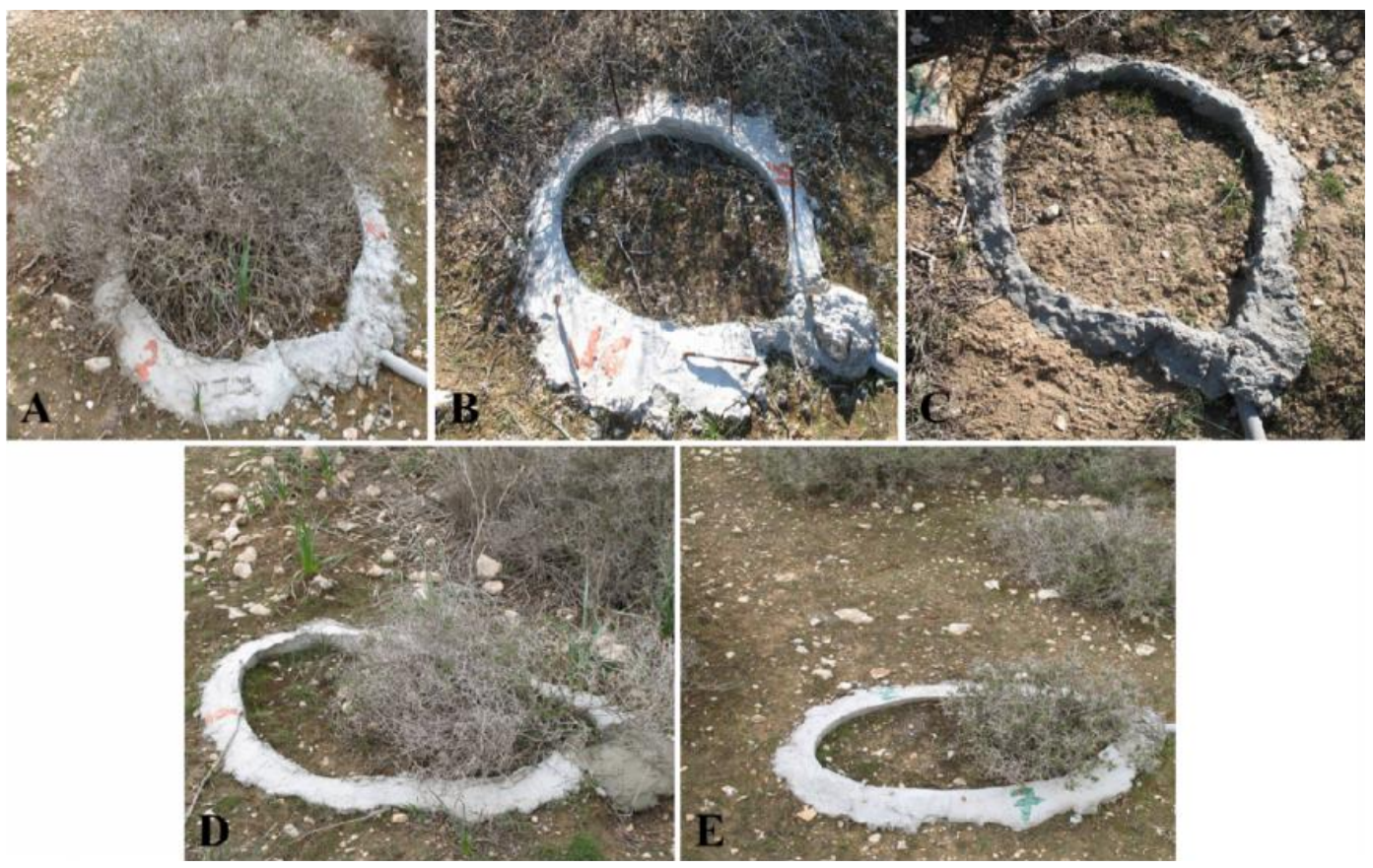

Figure 3. Small runoff plots: (a) - shrub (SH); (b) - intershrub area (IS); (c) - trampling route (RU); (d) - intershrub area + shrub (SI); (e) route $+\operatorname{shrub}(\mathrm{SR})$. (February 2008).

located in the lower part of the plot (Fig. 3). For each type of plot, three replicates were constructed.

The plots were bounded by concrete walls, $3-5 \mathrm{~cm}$ high, pegged to the ground and embedded $2 \mathrm{~cm}$ into the soil. A pipe, through which water was collected into a bucket embedded in the ground, was fitted at the topographically lower end of each plot.

Each bucket had a capacity of $10.5 \mathrm{~L}$, to ensure collection of the whole runoff yield from "bare ground" plots in heavy storms. In order to avoid loss of water in small rain events, small, $1 \mathrm{~L}$ receivers were mounted inside the buckets just beneath the entry pipes, and whenever the volume of collected runoff water did not exceed the capacity of the small receivers, they alone were taken to the laboratory. After each rain event, the buckets containing runoff water and sediment were replaced in the field, and were taken to the laboratory for determination of the gross weight of the runoff and sediment yields.

The amount of rainfall was measured by four small raingauges mounted perpendicularly to the slope, near the runoff plots, in order to measure the actual rainfall in the area.

\subsection{Laboratory work and statistical analysis}

The total yields of runoff and sediment were determined by weighing on the assumption that $1 \mathrm{~mL}$ of water weighs $1 \mathrm{~g}$. The sediment yield was calculated by oven-drying the runoff water for $24 \mathrm{~h}$ at $105^{\circ} \mathrm{C}$ and weighing the sediments left in the vessel. The sediment yield (g) was then subtracted from the total weight of (runoff water plus sediment), in order to determine the runoff volume $(\mathrm{mL})$. Statistical analyses were applied with EXCEL and SAS software. The runoff and sediment data were subjected to Duncan's non-parametric multiple-range test (Duncan, 1955) at the $p<0.05$ level of significance, to determine significant differences between microenvironments.

\section{Results}

\subsection{Rainfall}

In the 2007/8 and 2008/9 rainy seasons, the rainfall amounts reached 178.8 and $143.2 \mathrm{~mm}$, respectively, which are below the annual average in the research area, i.e., $300 \mathrm{~mm}$. In each season, most of the rain fell in January and February; i.e., more than $50 \%$ of the season's total rainfall fell during these 2 months (Fig. 4).

\subsection{Runoff yield}

In the two consecutive winters, 2007/8 and 2008/9, the minimal amount of rainfall, which generated runoff in the study area was $4 \mathrm{~mm}$ (Table 1). Among the 17 rain events in the season of 2007/8, overland flow was generated in only 10 events, and in the winter of 2008/9, runoff was generated in 7 out of 9 rain events.

Figure 5 shows the mean annual specific runoff yield (the volume of runoff per square meter) at the various plots for each year. For each plot, the annual mean was based on the 

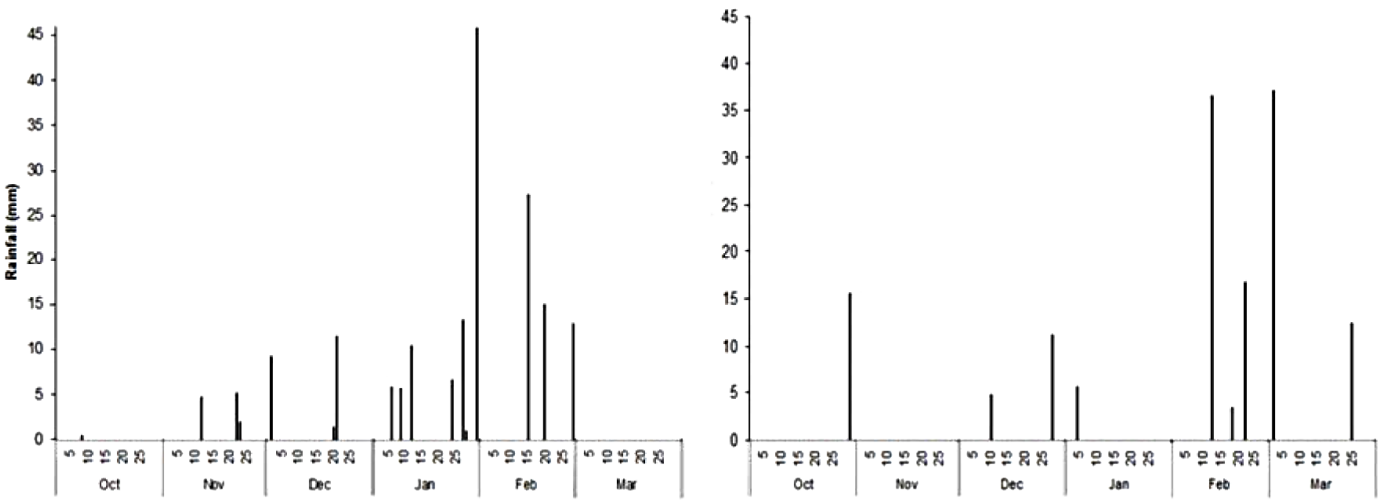

Winter 07-08

Winter 08-09

Figure 4. Rainfall (mm) distribution in 2007/8 and 2008/9.

Table 1. Rainfall, runoff and sediment events in the various plots, winters of 2007/8 and 2008/9. SH = shrub; IS =intershrub; RU = route; $\mathrm{SI}=$ intershrub + shrub; $\mathrm{SR}=$ route + shrub.

\begin{tabular}{lrlrrrrrrrrr}
\hline Date & Rainfall & \multicolumn{4}{c}{ Specific runoff $(\mathrm{mm})$} & \multicolumn{4}{c}{ Specific sediment $\left(\mathrm{g} \mathrm{m}^{-2}\right)$} \\
& $(\mathrm{mm})$ & SH & IS & RU & SI & SR & SH & IS & RU & SI & SR \\
\hline $08 / 10 / 2007$ & 0.5 & 0.0 & 0.0 & 0.0 & 0.0 & 0.0 & 0.0 & 0.0 & 0.0 & 0.0 & 0.0 \\
$12 / 11 / 2007$ & 4.2 & 0.0 & 0.1 & 0.3 & 0.0 & 0.0 & 0.0 & 0.9 & 3.0 & 0.0 & 0.0 \\
$22 / 11 / 2007$ & 5.6 & 0.0 & 0.0 & 0.0 & 0.0 & 0.0 & 0.0 & 0.0 & 0.0 & 0.0 & 0.0 \\
$23 / 11 / 2007$ & 2.0 & 0.0 & 0.0 & 0.0 & 0.0 & 0.0 & 0.0 & 0.0 & 0.0 & 0.0 & 0.0 \\
$02 / 12 / 2007$ & 8.2 & 0.4 & 3.2 & 3.7 & 0.4 & 0.3 & 0.1 & 21.5 & 29.4 & 0.4 & 0.9 \\
$20 / 12 / 2007$ & 1.0 & 0.0 & 0.0 & 0.0 & 0.0 & 0.0 & 0.0 & 0.0 & 0.0 & 0.0 & 0.0 \\
$21 / 12 / 2007$ & 12.0 & 1.6 & 6.9 & 5.9 & 0.9 & 1.5 & 2.5 & 41.8 & 24.3 & 0.6 & 2.5 \\
$06 / 01 / 2008$ & 6.2 & 0.0 & 0.0 & 0.0 & 0.0 & 0.0 & 0.0 & 0.0 & 0.0 & 0.0 & 0.0 \\
$09 / 01 / 2008$ & 5.7 & 0.0 & 0.0 & 0.0 & 0.0 & 0.0 & 0.0 & 0.0 & 0.0 & 0.0 & 0.0 \\
$12 / 01 / 2008$ & 10.6 & 0.0 & 0.5 & 0.6 & 0.0 & 0.0 & 0.0 & 0.6 & 0.8 & 0.0 & 0.0 \\
$24 / 01 / 2008$ & 6.8 & 0.0 & 0.5 & 0.5 & 0.0 & 0.0 & 0.0 & 0.4 & 0.2 & 0.0 & 0.0 \\
$27 / 01 / 2008$ & 12.6 & 1.2 & 4.8 & 4.8 & 0.4 & 0.4 & 1.7 & 6.0 & 5.8 & 0.2 & 0.3 \\
$28 / 01 / 2008$ & 1.0 & 0.0 & 0.0 & 0.0 & 0.0 & 0.0 & 0.0 & 0.0 & 0.0 & 0.0 & 0.0 \\
$31 / 01 / 2008$ & 46.3 & 7.8 & 31.4 & 31.0 & 3.9 & 8.1 & 5.2 & 73.1 & 32.6 & 2.6 & 1.5 \\
$15 / 02 / 2008$ & 28.2 & 0.9 & 14.7 & 14.3 & 1.2 & 1.3 & 1.0 & 56.1 & 26.4 & 0.5 & 0.7 \\
$20 / 02 / 2008$ & 15.2 & 0.0 & 3.3 & 4.8 & 0.2 & 0.1 & 0.0 & 2.0 & 3.1 & 0.1 & 0.1 \\
$28 / 02 / 2008$ & 12.7 & 0.2 & 8.7 & 7.9 & 0.7 & 0.3 & 0.3 & 54.3 & 34.1 & 0.5 & 0.4 \\
$30 / 10 / 2008$ & 15.0 & 0.0 & 0.2 & 0.6 & 0.0 & 0.0 & 0.0 & 0.7 & 2.6 & 0.0 & 0.0 \\
$10 / 12 / 2008$ & 5.0 & 0.0 & 1.5 & 2.1 & 0.0 & 0.1 & 0.0 & 8.4 & 19.6 & 0.0 & 0.3 \\
$28 / 12 / 2008$ & 10.7 & 0.1 & 0.6 & 1.0 & 0.1 & 0.1 & 0.1 & 0.7 & 0.7 & 0.0 & 0.5 \\
$04 / 01 / 2009$ & 5.7 & 0.0 & 0.0 & 0.0 & 0.0 & 0.0 & 0.0 & 0.0 & 0.0 & 0.0 & 0.0 \\
$12 / 02 / 2009$ & 36.8 & 8.0 & 19.3 & 19.8 & 6.7 & 5.6 & 27.9 & 211.3 & 91.7 & 7.2 & 5.2 \\
$18 / 02 / 2009$ & 3.3 & 0.0 & 0.0 & 0.0 & 0.0 & 0.0 & 0.0 & 0.0 & 0.0 & 0.0 & 0.0 \\
$22 / 02 / 2009$ & 16.7 & 0.9 & 8.9 & 9.9 & 1.1 & 1.0 & 0.9 & 27.6 & 20.3 & 0.8 & 0.6 \\
$02 / 03 / 2009$ & 36.5 & 0.3 & 24.4 & 25.9 & 2.2 & 3.7 & 0.0 & 181.1 & 111.1 & 1.0 & 1.8 \\
$25 / 03 / 2009$ & 13.5 & 0.2 & 4.0 & 4.1 & 0.8 & 0.2 & 0.3 & 7.7 & 5.7 & 0.5 & 0.1 \\
\hline & & & & & & & & & &
\end{tabular}

results of three replicates. It can be seen that the runoff generated in the various plots showed similar trends in all years: the combined plots - SI, SR and SH - yielded significantly less runoff than IS and RU, which yielded similar amounts to one another.

\subsection{Sediment yield}

Figure 6 shows the mean annual specific sediment yields (the weight of sediments per square meter) at the various plots for each year. Those of IS and RU were significantly higher than those of the combined plots, SI, SR and SH. 

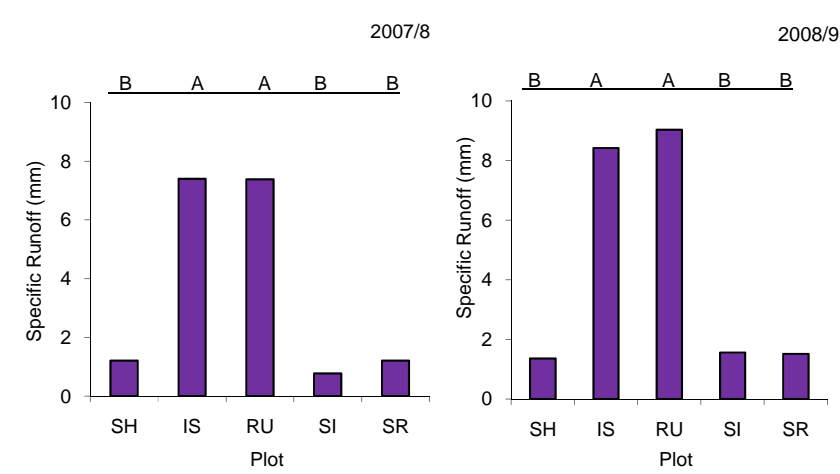

Figure 5. Runoff yield in the various plots; winter seasons 2007/8 and 2008/9. SH=shrub; IS = intershrub; RU = route; $\mathrm{SI}=$ intershrub + shrub; $\mathrm{SR}=$ route + shrub. Each value represents the mean of three replicates. For each year, means marked with different letters differ at $P<0.05$.

Among the various patch types, the highest specific sediment yield was obtained in IS, that in RU was lower (although not significantly so), and that in SH was significantly the lowest. This trend was observed in each year.

\section{Discussion}

\subsection{Patch functions}

A clear difference was apparent between the route and the intershrub plots on the one hand, and the combined plots - shrub + intershrub, and shrub + route - on the other hand (Figs. 5, 6). The intershrub plot yielded about 7 and 48 times more specific runoff and sediment deposits, respectively, than the combined shrub+intershrub plot; and the route plot yielded 6 and 28 times more specific runoff and sediment deposits, respectively, than the combined shrub + route plot. These relations were attributed primarily to the presence of shrubs in the combined plots: runoff and sediments that developed in the "bare" soil reached the shrubs, where a great part of them were trapped by the shrub and settled in situ, while the remaining (minor) part continued to flow. This ability of the shrubs to collect runoff resulted from the combined effects of several processes that enhance infiltration: the shrub canopy and the litter beneath it soften direct raindrop impact on the soil and dissipate their kinetic energy, thereby preventing formation of mechanical crusts and, in turn, enhancing infiltration (Rostango and del Valle, 1988; Dunkerley and Brown, 1995; Bromley et al., 1997). Moreover, shrubs act as a physical barrier that moderates overland flow velocity and continuity (Sanchez and Puigdefabregas, 1994); consequently, they trap soil and litter (Bergkamp, 1998; Shachak et al., 1998), forming soil mounds (Rostango and del Valle., 1988; Parsons et al., 1992) and thereby changing the surface microtopography as well as the soil texture and bulk density (Van Haveren, 1983; Trimble and Mendel 1995; Stavi et al., 2008b, 2009). The
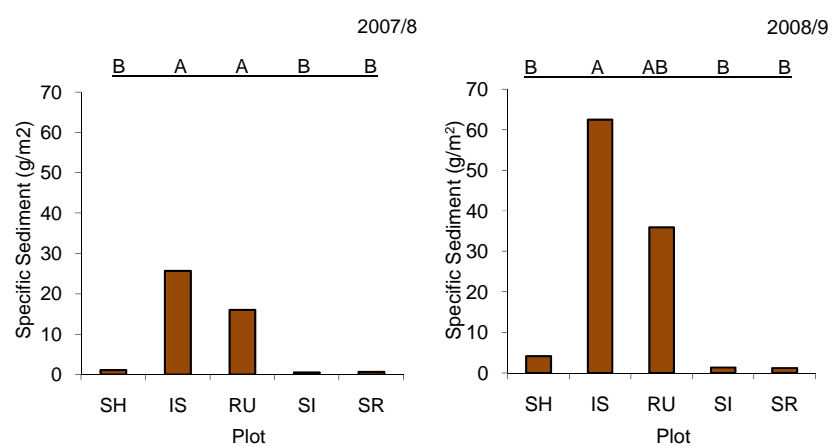

Figure 6. Sediment yield in the various plots; winter seasons 2007/8 and 2008/9. SH=Shrub; IS = Intershrub; RU = Route; $\mathrm{SI}=$ Intershrub + Shrub; $\mathrm{SR}=$ Route + Shrub. Each value represents the mean of three replicates. For each year, means marked with different letters differ at $P<0.05$.

combined physical, chemical and biological effects of shrub roots (Archer et al., 2002) and soil biological activity (Garner and Steinberger, 1989) improve soil organic matter content and structure (Oades, 1984; Sarah and Rodeh, 2004; Sarah, 2006), which reduces bulk density even more (Dunkerley and Brown, 1995), and creates macropores, in which water flows vertically at relative high rates (Bromley et al., 1997). Furthermore, in the study area the deepest soil was found beneath the shrubs. In addition, in a study conducted in a rangeland in the same region, Stavi et al. (2008a) suggested that loose sediments reached the upward-facing part of the downhill-located shrub, reduce the surface gradient and increase soil porosity, with the result that runoff velocity is reduced and continuity is interrupted, both of which enhance infiltration capacity (Bergkamp, 1998; Shachak et al., 1998).

The actual yields of runoff and sediments that were obtained in the present study confirm the role of shrubs as a sink for water and sediments, and that of the open areas between shrubs, i.e., intershrubs and routes, as sources.

\subsection{Importance of the function of trampling routes and intershrubs as sources}

The yields of runoff and sediments from the various patches in semi-arid study site spring from the combined effects of herbivory and trampling, on the one hand (Golodets and Boeken, 2006), and nutrient addition in the forms of urine and dung, on the other hand (McNaughton, 1979).

\subsubsection{Runoff yield}

The relative differences in runoff between the intershrub and shrub, and between route and shrub were similar in each of the years: route and intershrub yielded 6 times more runoff than the shrub. These findings indicate the balance between favorable and unfavorable environmental conditions in the patches. 
The loess soil of the study area, including that of the various patches, contains 20-30\% clay (Ben-Hur et al., 1985; Zwikel et al., 2007) in which smectite is the dominant component (Shainberg et al., 1990). This soil is sensitive to physical and chemical disruption of aggregates and is subject to dispersion of clay particles, which clog the pores of the upper soil layer (Agassi et al., 1981; Shainberg et al., 1990). The intershrub patches are characterized by a dense cover of annual and perennial herbaceous vegetation (geophytes, grasses and forbs) and bare soil. The loess soil is partially compacted by sporadic trampling by livestock, with consequent mechanical formation of crust, which is commonly developed in this area. The trampling routes have the highest soil compaction and a sparse covering of herbaceous plants, which can be attributed directly to the impact of intense animal traffic: hoof action damages and detaches tissue from growing plants (Pande and Yamamoto, 2006), thereby reducing canopy and herbaceous cover, and increasing the exposure of bare soil. The animal trampling compacts the soil, thereby increasing soil bulk density (Schlesinger et al., 1990; Stavi et al., 2008a) and destroying the topsoil structure (Manzano and Navar, 2000), especially along flock trampling routes (Warren et al., 1996; Stavi et al., 2008b). These processes enhance subsequent rain splash and thereby increase mechanical crusting and surface sealing of the soil (Wilcox et al., 1988; Bari et al., 1993), which eventually reduces infiltration into the soil and promotes surface runoff (Manzano and Navar, 2000; Sarah, 2002) from the "no shrub" patches, i.e., route and intershrub. Also, these patches vary in their inclination, which is lower in the route than in the intershrub, at $4-6^{\circ}$ and $13-15^{\circ}$, respectively (Stavi et al., 2008a), because of the animal trampling that smoothes the surface of the former (Nash et al., 2003, 2004).

On the one hand, the higher soil compaction and lower vegetation cover in the route tend to promote runoff but, on the other hand, their lower gradients tend to reduce it. In contrast, in the intershrub the runoff is influenced by the same factors acting in the opposite senses; i.e., lower soil compaction and higher vegetation cover tend to reduce runoff, whereas higher gradients tend to promote it. Thus, the balance between factors that promote runoff generation and those that reduce it is similar; therefore, runoff yields in the route and intershrub were similar.

The similarity between the runoff yields, which indicates that there was no difference between the water contributions of the route and of the intershrub, contradicts part of the hypothesis that: "the three types of surface cover/patches differ in their responses to rainfall". We found that only the shrub patch differed from the other two patches.

Observations during the 2 years of the present study showed that no runoff was contributed to the channel from the hillslopes. Kosovsky (1994) studied rainfall/runoff/infiltration processes in two low-order drainage basins, which are located in the present study area; he recorded no more than two stream flows in the basins during the winters of 1990/91 and 1991/92, when the annual rainfall was 266 and $376 \mathrm{~mm}$, respectively. The differences between Kosovsky's (1994) study and the present one can be explained by the difference in the annual rainfall amount which affects runoff connectivity. The winters of the present study were dry (2007/08 and 2008/09 - annual rainfall of 179 and $143 \mathrm{~mm}$, respectively. The runoff generated in the sources was dispersed and infiltrated beneath the shrub; thus, no connectivity of runoff sources occurred. In the wetter winters of Kosovsky's study, large areas of the hillslope were saturated, caused an increase in runoff connectivity; thus, stream flows occurred. This means that in this semiarid area the existing spatial pattern of the main surface components expresses optimal efficiency in maintaining the hillslope ecosystem through dry years and wet years as well.

\subsubsection{Sediment yield}

In contrast to runoff, the relative differences in sediment yield between each of the two source patches and the sink patch were different. In both years the differences between the intershrub and shrub were higher than those between the route and shrub: by average factors of 16.9 and 9.8, respectively, in both years. As described above, the lower local gradients and greater soil compaction in the route than in the intershrub result in dense organization of soil particles, which reduces their vulnerability to shear stress and erosion. Such compaction prevents biological activity and thereby reduces the proneness of available sediments to erosion. This means that the intershrub patches are the ones most susceptible to soil erosion; therefore, they are the main providers of nutrients to shrubs, because they have a higher organic matter content than the routes (Stavi et al., 2008b).

The finding that the route yielded less sediments than the intershrub contradicts the hypothesis presented in the Introduction, that "the routes and the shrubs have highest and lowest outputs of overland flow and sediments, respectively, with those from the intershrubs falling between them".

\subsection{Runoff-erosion relations}

A comparison among the runoff/erosion ratios of the patches revealed that each millimeter of runoff eroded sediments at $3.4,2.2$, and $0.9 \mathrm{~g} \mathrm{~m}^{-2}$ from the intershrub, route, and $\mathrm{SH}$ patches, respectively. Shrubs reduce soil runoff-driven erosion because of the combined effects of consolidation of soil aggregates - by roots, and high contents of organic matter and soil moisture - and the low energy of the runoff on the flattened microtopography. The erosive effect of runoff is weaker in the route than in the intershrub for the reasons described under "The importance of the function of trampling routes and intershrubs as sources". Therefore, the SH and route patches exhibited pronounced self-regulation of erosion processes, whereas the intershrub did not. 
On the one hand, the soil texture of the research site, especially the relatively low percentage of clay particles, leads to mechanical crust formation but, on the other hand, the clay percentage is not high enough for its cohesive forces to maintain aggregate stability. This effect is exacerbated by the high content of the highly dispersive smectite, which is the dominant clay particle type in loess soils in the study area. Thus, it cannot necessarily be concluded that similar findings, i.e., runoff and sediment yields, could be expected to occur in soils having other clay contents and/or types.

\subsection{Runoff coefficient}

Runoff coefficients (ratio between runoff and rainfall), at the scale of measurement, obtained in the present study were higher than those found in previous field studies. The annual runoff coefficients found in the present study reached 0.4 and 0.45 in 2007/8 and 2008/9, respectively, in the route and intershrub patches. Cerdà (1988a) found a runoff coefficient of 0.12 in simulated rainfall experiments on a south-facing slope with underlying limestone in south-east Spain. CalvoCases et al. (2003) found a runoff coefficient of 0.16 in a calcareous site in a semi-arid environment with mean annual rainfall and temperature of $387 \mathrm{~mm}$ and $17.9^{\circ} \mathrm{C}$, respectively, and Puigdefabregas et al. (1999) found a runoff coefficient of 0.1 in a single $66 \mathrm{~mm}$ rain event in a mica-schist bedrock site in semi-arid environment with mean annual rainfall and temperature of $300 \mathrm{~mm}$ and $16^{\circ} \mathrm{C}$, respectively. The differences among the above findings could be attributed to ecological and physical differences among the sites - differences mostly in soil properties, especially texture, i.e., clay content and mineralogy, and in vegetation, surface gradient, rainfall intensity, land use and plot size.

\subsection{Land use practice}

Over-exploitation of natural or seminatural rangeland areas by overgrazing and/or by using the shrubs as a fuel source will cause gradual homogenization of the ground surface, leading to increasing continuity of overland flow generation and soil erosion at the hillside scale. This means decreased functionality of the ecosystem.

Human activity causes changes of the soil cover and calls for new solutions to cope with these changes. New surfaces have appeared in most landscapes in many parts of the world because of the dramatic increases in road construction over the last few decades. Also, abandoned mines and abandoned agricultural areas present environmental problems because of increased soil erosion, the loss of large areas that have become unexploited, and for aesthetic reasons. Practical suggestions for reclamation of such areas included planting vegetation; Haigh et al. (2013) concluded that providing a loosened, lower-density, rooting substrate significantly improved both the growth and the survival rates of trees planted in compacted Welsh surface coal-mine spoils, and that trench plant- ing was more effective than park- and garden-style pit planting, which, in turn, is more effective than forestry-style notch planting. Lee et al. (2013) showed that using a digger to drill holes for planting vegetation was a cost-effective revegetation technology for stabilizing road cuttings in southwest Korea; they indicated that erosion-control species, Poa pratensis L. and Eragrostis curvula (Schrad.) Nees survived and grew better than native woody species. Jimenez et al. (2013), in their research on embankments of a highway in Central Spain identified establishment of vegetation and promotion of soil formation as key restoration practices related to ecological processes. Jiménez et al. (2014) found that mulching treatments that were applied to seedlings had great influence on soil properties and on the field performance of afforested holm oak seedlings (Quercus ilex L. subsp. ballota (Desf.) Samp.) in an abandoned agricultural field in SE Spain.

All the above practices include revegetation as a useful tool for reclamation of the above human-affected areas. The present findings support use of the plant/soil pattern as a possible practice for preventing runoff and soil erosion in road cuttings and abandoned mines in semi-arid areas, i.e., planning of revegetation according to the three-phase mosaic pattern. The patches of this pattern differ in their hydrological and erosion-related functions: the shrubs collect runoff and sediments from the intershrub and route areas of the upper hillslopes. In addition, the routes moderate the gradient of the road margins, and thereby reduce the intensity of runoff and erosion processes. More studies are needed to evaluate the effectiveness of this management pattern on the abovediscussed areas. Such studies need to relate to such questions: is seeding of herbaceous plants in the intershrub areas necessary in all climatic regions and in all soils? What shape of shrub canopy or root density distribution will achieve the optimal effect in preventing runoff generation and in stabilizing the slope? For how long need active modification/control of soil structure continue? For example, can the soil beneath the shrubs be left to develop a natural soil structure, while the soil in the open areas is compacted in order to promote overland flow which supports the shrubs? Does the soil in the open areas need to be stabilized with amendments (such as PAM - polyacrylamide) and for how long, in order to moderate the potential for erosion processes and to enable successful germination and growth? What are the optimal distances between shrubs (sinks) and between routes (sources)? In addition, the financial costs of the above treatments need to be considered.

\section{Conclusions}

Under the environmental conditions that prevailed in the studied rangelands, i.e., moderately intense grazing by 800 livestock units on 800 ha, the shrubs absorbed almost all of the resources produced in the routes and intershrubs. 
Similarly to a two-phase mosaic, a pattern was confirmed for the runoff yield only; i.e., the only difference found was that between the shrubs, on the one hand, and the open spaces, routes, and intershrubs, on the other hand, with no differences between the latter two patches. However, erosion processes showed a "three-phase-mosaic" pattern in which a considerable part of sediments were eroded from the intershrubs, a smaller part from the routes, and, conspicuously, the least from the shrubs.

It is not necessarily concluded that similar findings, i.e., patterns of runoff and sediment yields, could be expected to occur in soils having other different clay content and/or types, and in rainier years.

The intershrub patches are the ones most susceptible to soil erosion; therefore, they are the main providers of nutrients to shrubs.

The routes play an important role in ecosystem functioning by influencing the spatial redistribution of resources at the patch scale. Such non-trophic effects can be regarded as the actions of an ecosystem engineer, i.e., an organism that regulates the productivity of other organisms by controlling their resource supply or by modifying their habitat.

Acknowledgements. We thank N. Fragin, Mr. E. Sachs and Mr. D. Meir from the Laboratory of Geomorphology and Soil, Bar-Ilan University, Israel, for their field work assistance.

Edited by: P. Pereira

\section{References}

Abrahams, A. D. and Parsons, A. J.: Relation between infiltration and stone cover on a semiarid hillslope, southern Arizona, J. Hdrol., 122, 49-59, 1991.

Agassi, M., Shainberg, I., and Morin, J.: Effect of electrolyte concentration and soil sodicity on infiltration rate and crust formation, Soil Sci. Soc. Am. J., 45, 848-851, 1981.

Álvarez-Martínez, J., Gómez-Villar, A., and Lasanta, T.: The use of goats grazing to restore pastures invaded by shrubs and avoid desertification: a preliminary case study in the Spanish Cantabrian mountains, Land Degrad. Dev., doi:10.1002/ldr.2230, 2013.

Angassa, A.: Effects of grazing intensity and bush encroachment on herbaceous species and range condition in Southern Ethiopia, Land Degrad. Dev., 25, 438-451 doi:10.1002/ldr.2160, 2012.

Archer, N. A., Quinton, L. J. N., and Hess, T. M.: Below-ground relationships of soil texture, roots and hydraulic conductivity in two-phase mosaic vegetation in south-east Spain, J. Arid Environ., 52, 535-553, 2002.

Arnau-Rosalén, E., Calvo-Cases, A., Boix-Fayos, C., Lavee, H., and Sarah, P.: Analysis of soil surface component patterns affecting runoff generation. An example of methods applied to Mediterranean hillslopes in Alicante (Spain), Geomorphology, 101, 595606, 2008.

Bar'am, H.: Meteorological data. Lehavim Hills, Israel (1987-95), Volcani Institute, Bet Dagan, Israel, 31 pp., 1996 (in Hebrew).
Bari, F., Wood, M. K., and Murray, L.: Livestock grazing impacts on infiltration rates in a temperate range of Pakistan, J. Range Manage., 46, 367-372, 1993.

Ben-Hur, M., Shainberg, I. Baker, D., and Keren, R.: Effects of soil texture and $\mathrm{CaCO}_{3}$ content on water infiltration in crusted soil as related to water salinity, Irrigation Sci., 6, 281-294, 1985.

Ben-Shmuel, M.: The effect of shrubs on the spatial distribution of overland flow and sediment yield in different climatic regions, $\mathrm{M}$. A. thesis, Bar-Ilan University, Ramat-Gan, Israel, 55 pp., 2005 (in Hebrew, English Abstract).

Bergkamp, G.: A hierarchical view of the interactions of runoff and infiltration with vegetation and micro-topography in semiarid shrublands, Catena, 33, 201-220, 1998.

Bennett, J. E., Palmer, A. R., and Blackett, M. A.: Range degradation and land tenure change: insights from a "released" communal area of eastern cape province, South Africa, Land Degrad. Dev., 23, 557-568, doi:10.1002/ldr.2178, 2012.

Bitan, A. and Rubin, S.: Climatic atlas of Israel for physical and environmental planning and design, Department of Geography, Tel Aviv University, Tel Aviv, and Israel Meteorological Service, Ministry of Transport, Bet Dagan, 1991

Bromley. J., Brouwer, J., Barker, A. P., Gaze, S. R., and Valentin, C.: The role of surface water redistribution in an area of patterned vegetation in a semi-arid environment, south-west Niger, J. Hydrol., 198, 1-29, 1997.

Bryan, R. B.: Soil erodibility and processes of water erosion on hillslopes, Geomorphology 32, 385-415, 2000.

Calvo-Cases, A., Boix-Fayos, C., and Imeson, A. C.: Runoff generation, sediment movement and soil water behavior on calcareous (limestone) slopes of some Mediterranean environments in southeast Spain, Geomorphology, 50, 269-291, 2003.

Carreiras, M., Ferreira, A. J. D., Valente, S., Fleskens, L., GonzalesPelayo, Ó., Rubio, J. L., Stoof, C. R., Coelho, C. O. A., Ferreira, C. S. S., and Ritsema, C. J.: Comparative analysis of policies to deal with the wildfire risk, Land Degrad. Dev., 25, 92-103, doi:10.1002/ldr.2271, 2014.

Cerdà, A.: The effect of patchy distribution of Stipa tenacissima L. on runoff and erosion, J. Arid Environ., 36, 37-51, doi:10.1006/jare.1995.0198, 1997.

Cerdà, A.: The influence of geomorphological position and vegetation cover on the erosional and hydrological processes on a Mediterranean hillslope, Hydrol. Process., 12, 661-671, 1998a.

Cerdà, A.: Changes in overland flow and infiltration after a rangeland fire in a Mediterranean scrubland, Hydrol. Process., 12, 1031-1042, 1998b.

Cerdà, A.: Effect of climate on surface flow along a climatological gradient in Israel. A field rainfall simulation approach, J. Arid Environ., 38, 145-159, 1998c.

Cerdà, A.: Soil aggregate stability under different Mediterranean vegetation types, Catena, 32, 73-86, 1998d.

Cerdà, A., Hooke, J., Romero-Diaz, A., Montanarella, L., and Lavee, H.: Soil erosion on Mediterranean Type-Ecosystems, Land Degrad. Dev., 21, 71-217, doi:10.1002/ldr.968, 2010.

Dan, J. and Koyumdjisky, H.: Israel soil classification, Special Publication 137, Volcani Center, Bet Dagan, Israel, 94 pp., 1979 (in Hebrew)

Dickie, J. A. and Parsons, A. J.: Eco-geomorphological processes within grasslands, shrublands and badlands in the semi- 
arid Karoo, South Africa, Land Degrad. Dev., 23, 534-547, doi:10.1002/ldr.2170, 2012.

Duncan, D. B.: Multiple range and multiple F-test, Biometric, 11, $1-42,1955$.

Dunkerley, D. L. and Brown, K. J.: Runoff and runon areas in a patterned chenopod shrubland, arid western New South Wales, Australia: characteristics and origin, J. Arid Environ., 30, 41-55, 1995.

Eddy, J., Humphreys, G. S., Hurt, D. M., Mitchell, P. B., and Fanning, P. C.: Vegetation arcs and litter dams: similarities and differences, Catena, 37, 57-73, 1999.

Eldridge, D. J., Zaady, E., and Shachak, M.: Infiltration through three contrasting biological soil crusts in patterned landscapes in the Negev, Israel, Catena, 40, 323-336, 2000.

Galle, S., Ehrmann, M., and Peugeot, C.: Water balance in a banded vegetation pattern, a case study of tiger bush in western Niger, Catena 37, 197-216, 1999.

Garner, W. and Steinberger, Y.: A proposed mechanism for the formation of "fertile islands" in the desert ecosystem, J. Arid Environ., 16, 257-262, 1989.

Golodets, C. and Boeken, B.: Moderate sheep grazing in semiarid shrubland alters small-scale soil surface structure and patch properties, Catena, 65, 285-291, 2006.

Haigh, M., Reed, H., Flege, A., D’Aucourt, M., Plamping, K., Cullis, M., Woodruffe, P., Sawyer, S., Panhuis, W., Wilding, G., Farrugia, F., and Powell, S.: Effect of planting method on the growth of Alnus glutinosa and Quercus petraea in compacted opencast coal-mine spoils, south Wales, Land Degrad. Dev., 26, 227-236, doi:10.1002/ldr.2201, 2013.

Imeson, A. C., Lavee, H., Calvo, A., and Cerda, A.: The erosional response of calcareous soils along a climatological gradient in Southeast Spain, Geomorphology, 24, 3-16, 1996.

Jiménez, M. D., Ruiz-Capillas, P., Mola, I., Pérez-Corona, E., Casado, M. A., and Balaguer, L.: Soil development at the roadside: a case study of a novel ecosystem, Land Degrad. Dev., 24, 564-574, doi:10.1002/ldr.1157, 2013.

Jiménez, M. N., Fernández-Ondoño, E., Ripoll, M. Á., CastroRodríguez, J., Huntsinger, L., and Navarro, F. B.: Stones and organic mulches improve the Quercus ilex L. afforestation success under Mediterranean climate conditions, Land Degrad. Dev., doi:10.1002/ldr.2250, 2014.

Jones, C. G., Lawton, J. H., and Shachak, M.: Organisms as ecosystem engineers, Oikos, 69, 373-386, 1994.

Jones, C. G., Lawton, J. H., and Shachak, M.: Positive and negative effects of organisms as physical ecosystem engineers, Ecology, 78, 1946-1957, 1997.

Jones, N., de Graaff, J., Duarte, F., Rodrigo, I., and Poortinga, A.: Farming systems in two less favoured areas in Portugal: their development from 1989 to 2009 and the implication for sustainable land management, Land Degrad. Dev., 25, 29-44, doi:10.1002/ldr.2257, 2014.

Kakembo, V., Ndlela, S., and Cammeraat, E.: Trends in vegetation patchiness loss and implications for landscape function: the case of Pteronia incana invasion in the Eastern Cape Province, South Africa, Land Degrad. Dev., 23, 548-556, doi:10.1002/ldr.2175, 2012.

Katra, I., Blumberg, D. G., Lavee, H., and Sarah, P.: Top soil moisture patterns on arid hillsides- micro-scale mapping by thermal infrared images, J. Hydrol, 334, 359-367, 2007.
Kosovsky, A.: Overland flow in a semiarid region Lahav Hills, Israel. M.Sc. thesis, Hebrew University of Jerusalem, Israel, 115 pp., 1994 (in Hebrew, English Abstract).

Kröpfl, A. I., Cecchi, G. A., Villasuso, N. M., and Distel, R. A.: Degradation and recovery processes in Semi-Arid patchy rangelands of northern Patagonia, Argentina, Land Degrad. Dev., 24, 393-399, doi:10.1002/ldr.1145, 2013.

Lasanta, T. and Cerdà, A.: Long-term erosional responses after fire in the Central Spanish Pyrenees: 2. Solute release, Catena, 60, 81-100, 2005.

Lavee, H., Imeson, A., Pariente, S., and Benyamini Y.: The response of soils to simulated rainfall along a climatological gradient in an arid and semi-arid region, Catena Suppl., 19, 19-37, 1991.

Lavee, H., Imeson, A. C., and Sarah, P.: The impact of climate change on geomorphology and desertification along a Mediterranean-arid transect, Land Degrad. Dev., 9, 407-422, 1998.

Lee, J.-W., Park, C.-M., and Rhee, H.: Revegetation of decomposed granite roadcuts in Korea: Developing Digger, evaluating cost effectiveness, and determining dimension of drilling holes, revegetation species, and mulching treatment, Land Degrad. Dev., 24, 591-604, doi:10.1002/ldr.2248, 2013.

Li, X. and Sarah, P.: Arylsulfatase activity of soil microbial biomass along a Mediterranean - arid transect, Soil Biol. Biochem., 35, 925-934, 2003.

Ludwig, J. A., Tongway, D. J., and Marsden, S. G.: Stripes, strands or stipples: modeling the influence of three landscape banding patterns on resource capture and productivity in semi-arid woodlands, Australia, Catena, 37, 257-273, 1999.

Manzano, M. G. and Navar, J.: Processes of desertification by goats overgrazing in the Tamaulipan thornscrub (matorral) in northeastern Mexico, J. Arid Environ., 44, 1-17, 2000.

McNaughton, S. J.: Grazing as an optimization process: grassungulate relationships in the Serengeti, Am. Nat., 113, 691-703, 1979.

Mekuria, W. and Aynekulu, E.: Exclosure land management for restoration of the soils in degrade communal grazing lands in Northern Ethiopia, Land Degrad. Dev., 24, 528-538, doi:10.1002/ldr.1146, 2013.

Mulale, K., Chanda, R., Perkins, J. S., Magole, L., Sebego, R. J., Atlhopheng, J. R., Mphinyane, W., and Reed, M. S.: Formal institutions and their role in promoting sustainable land management, Land Degrad. Dev., 25, 80-91, doi:10.1002/ldr.2274, 2014.

Nash, M. S., Jackson, E., and Whitford, W. G.: Soil microtopography on grazing gradients in Chihuahuan desert grassland, J. Arid Environ., 55, 181-192, 2003.

Nash, M. S., Jackson, E., and Whitford, W. G.: Effects of intense, short-duration grazing on microtopography in a Chihuahuan Desert grassland, J. Arid Environ., 56, 383-393, 2004.

Noy-Meir, I. and Seligman, N.: Management of semi-arid ecosystems in Israel, in: Management of semi-arid ecosystems, edited by: Walker B. H., Elsevier Amsterdam, Netherlands, 113-160, 1987.

Oades, J. M.: Soil organic carbon and structural stability: mechanisms and implications for management, Plant Soil, 76, 319-337, 1984.

Osem, Y., Perevolotsky, A., and Kigel, J.: Grazing effect on diversity of annual plant communities in a semi-arid rangeland: inter- 
actions with small-scale spatial and temporal variation in primary productivity, J. Ecol., 90, 936-946, 2002.

Pande, T. N. and Yamamoto, H.: Cattle treading effects on plant growth and soil stability in the mountain grassland of Japan, Land Degrad. Dev., 17, 419-428, doi:10.1002/ldr.747, 2006.

Parsons, A. J., Abrahams, A. D., and Simanton, J. R.: Microtopography and soil-surface materials on semi-arid piedmont hillslopes, southern Arizona, J. Arid Environ., 22, 107-115, 1992.

Perevolotsky, A. and Landau, Y.: Improvement and development of the Bedouin stock industry in the northern Negev, Lehavim demonstration farm, Professional report 1982-1988, Department of Natural Resources, Institute of Field and Garden Crops, Agricultural Research Organization, Bet Dagan, Israel, 1988 (in Hebrew).

Puigdefabregas, J. and Sanchez, G.: Geomorphological implications of vegetation patchiness in semi-arid slopes, in: Anderson, M. and Brooks, S., Advances in hillslope processes, Wiley, London, 1027-1060, 1996.

Puigdefabregas, J., del Barrio, G., Boer, M., Gutierrez, L., and Sole, A.: Differential responses of hillslope and channel elements to rainfall events in a semi-arid area, Geomorphology, 23, 337-351, 1998.

Puigdefábregas, J., Solé, A., Gutiérrez, L., del Barrio, G., and Boer, M.: Scales and processes of water and sediment redistribution in drylands: results from the Rambla Honda field site in Southeast Spain, Earth Sci. Rev., 48, 39-70, 1999.

Qian, J., Wang, Z., Liu, Z., and Busso, C. A.: Belowground bud bank response to grazing intensity in the inner-Mongolia steppe, China. Land Degrad. Dev., doi:10.1002/ldr.2300, 2014.

Ravikovitch, S.: The Soils of Israel, Formation, Nature and Properties, Hakibbitz Hameuchad Publishing House, Tel-Aviv, pp. 489, 1981 (in Hebrew, English Abstract).

Rietkerk, M., Boerlijst, M. C., van Langevelde, F., HilleRisLambers, R., van de Koppel, J., Kumar, L., Prins, H. H. T., and de Roos, A. M.: Self-organization of vegetation in arid ecosystems, Am. Nat., 160, 524-530, 2002.

Rostango, C. M. and del Valle, H. F.: Mounds associated with shrubs in aridic soils of northeastern Patagonia: characteristics and probable genesis, Catena, 15, 347-359, 1988.

Sanchez, G. and Puigdefabregas, J.: Interaction between plant growth and sediment movement in semi-arid slopes, Geomorphology, 9, 243-260, 1994.

Sarah, P.: Spatial patterns of soil moisture as affected by shrubs, in different climatic conditions, Environ. Monit. Assess., 73, 237241, 2002.

Sarah P.: Non-linearity of ecogeomorphic processes along Mediterranean-arid transect, Geomorphology, 60, 303-317, 2003.

Sarah, P.: Soil organic matter and land degradation in semi-arid area, Israel, Catena, 67, 50-55, 2006.

Sarah, P.: Pedo-hydrological patchiness in the Northern Negev, Israel, as affected by grazing, Ecol. Noospheology, 20, 164-165, 2009

Sarah, P. and Rodeh, Y.: Soil structure variations under water and vegetation manipulations, J. Arid Environ., 58, 43-57, 2004.
Shachak, M., Sachs, M., and Moshe, I.: Ecosystem management of desertified shrublands in Israel, Ecosystems, 1, 475-483, 1998.

Shainberg, I., Warrington, D. N., and Rengasamy, P.: Water quality and PAM interactions in reducing surface sealing, Soil Sci., 149, 301-307, doi:10.1097/00010694-199005000-00007, 1990.

Shang, Z., Cao, J., Guo, R., Henkin, Z., Ding, L., Long, R., and Deng, B.: Effects of enclosure on soil carbon, nitrogen and phosphorus of Alpine desert rangeland, Land Degrad. Dev., doi:10.1002/ldr.2283, 2014.

Stavi, I., Ungar, U., Lavee, H., and Sarah, P.: Surface microtopography and soil penetration resistance associated with shrub patches in a semiarid rangeland, Geomorphology, 94, 69-78, 2008a.

Stavi, I., Ungar, U., Lavee, H., and Sarah P.: Grazing-induced spatial variability of soil bulk density and content of moisture, organic carbon and calcium carbonate in a semi-arid rangeland, Catena, 75, 288-296, 2008b.

Stavi, I., Ungar, U., Lavee, H., and Sarah P.: Livestock modify ground surface microtopography and penetration resistance in a semi-arid shrubland, Arid Land Res. Manag., 23, 237-247, 2009.

Stavi, I., Ungar, U., Lavee, H., and Sarah, P.: Grazing-induced modification of a semi-arid rangeland from two-phase to three-phase mosaic geo-ecosystem, Arid Land Res. Manag., 26, 79-83, 2012.

Tongway, D. J. and Ludwig, J. A.: The nature of landscape dysfunction in rangelands, in: Ludwig, J. A., Tongway, D. J., Freudenberger, D., Noble, J. and Hodgkinson, K., Landscape ecology function and management, CSIRO Publishing, Canberra, 49-61, 2003.

Trimble, S. W. and Mendel, A. C.: The cow as geomorphic agent a critical review, Geomorphology, 13, 233-253, 1995.

Van Haveren, B. P.: Soil bulk density as influenced by grazing intensity and soil type on a short grass prairie site, J. Range Manage. 36, 586-588, 1983.

Vetter, S. and Bond, W. J.: Changing predictors of spatial and temporal variability in stocking rates in a severely degraded communal rangeland, Land Degrad. Dev., 190-199, doi:10.1002/ldr.1076, 2012.

Warren, S. D., Thurow, T. L., Blackburn, W. H., and Garza, N. E.: The influence of livestock trampling under intensive rotation grazing on soil hydrologic characteristics, J. Range Manage., 39, 491-495, 1986.

Wilcox, B. P., Wood, M. K., and Tromble, J. M.: Factors influencing infiltrability of semiarid mountain slopes, J. Range Manage., 41, 197-206, 1988.

Yair, A. and Lavee, H.: An investigation of source areas of sediment and sediment transport by overland flow along arid hillslopes, Erosion and sediment transport measurement, IAHS Publication, 133, 433-446, 1981.

Yair, A. and Lavee, H.: Runoff generation in arid and semi-arid zones, in: Hydrological Forecasting, edited by: Anderson M. G. and Burt, T. P., Wiley, New York, 183-220, 1985.

Zwikel, S., Lavee, H., and Sarah, P.: Temporal dynamics of arylsulfatase enzyme activity in various microenvironments along a climatic transect in Israel, Geoderma, 140, 30-41, 2007. 